\title{
USAGE OF PLANT INGREDIENTS AS ANTIOXIDANTS FOR FOOD PRODUCTION
}

\author{
Lozova Tetiana*, Syrokhman Ivan, Kalymon Marta-Mariia
}

Lviv Trade and Economic University, Lviv, Ukraine

\section{ВИКОРИСТАННЯ РОСЛИННИХ ІНГРЕДІЄНТІВ ЯК АНТИОКСИДАНТІВ ДЛЯ ВИРОБНИЦТВА ХАРЧОВИХ ПРОДУКТІВ}

\author{
Лозова Тетяна, Сирохман Іван, Калимон Марта-Марія \\ Received 3. 4. 2017 \\ Revised 22. 5. 2017 \\ Published 29.11. 2017
}

The article presents the results of the study of antioxidant properties of plant powders of common elder (Sambucus nigra L.) and little-leaved linden (Tilia cordata Mill) flowers. Powders were put to the confectionery fat at a concentration of 1 and $2 \%$ by weight of fat. The fat sample with no additives was as a control. The experimental studies were conducted in the model conditions of the accelerating kinetic method by the temperature of $(90 \pm 2){ }^{\circ} \mathrm{C}$ with free access to oxygen. The change of fat quality was controlled by the content of oxidation products - primary (peroxidation number), secondary (benzidine number) and products of hydrolysis (acid number). Among the studied plant ingredients, the powder of common elder flowers, at a concentration of $1.0 \%$ by weight of fat, provided the reduction of the quantities of peroxide number in 1.3-1.55 times. Increased concentrations of powder to $2.0 \%$ led to the creation of the antioxidant effect in 1.34-1.60 times. According to the peroxide value, the powder of little-leaved linden flowers (1.0\%) exceeded the effectiveness of the common elder flowers (1.0\%) in 1.1 times. In the sample of fat with this additive, the content of peroxides is reduced to 1.36-1.72 times for the entire period of storage. In neighbor value of the degree of the primary oxidation in the sample of fat with the addition of $2.0 \%$ powder of little-leaved linden flowers, the number of peroxides in 1.39-1.83 times compared to $1.0 \%$ of this additive, nevertheless was managed to reduce. The benzidine number of confectionery fat due to the addition of these herbal powders turned lower in 1.2-1.7 times during monitoring and acid number - in 1.15-2.80 times. Thus, it is proved that their adding to the confectionery fat allows to slow down the processes of oxidation and hydrolysis of fat in 1.20-1.83 times regarding the control sample. The powder of little-leaved linden flowers showed higher efficiency. The obtained results make it possible to conclude that the use of studied additives as the plant ingredients in the production of fat-containing flour confectionery products of high biological value with a view to extending its storage is possible.

Keywords: plant ingredients; antioxidants; supplements; food products

\section{Вступ}

Правильно збалансований раціон може захистити населення від деяких найбільш поширених сьогодні захворювань, а також сповільнити старіння організму. Погіршення екологічної ситуації обумовлює необхідність у розробці харчових форм біозахисної дії. За умов ослаблення

\footnotetext{
*Corresponding author: Tetiana Lozova, Lviv Trade and Economic University, Lviv, Ukraine, $\triangle$ lozovatm@gmail.com
} 
організму відбувається масове утворення вільних радикалів, які можуть бути причиною багатьох захворювань. У цьому випадку організму людини особливо потрібні біологічно активні речовини, які допомагають адаптуватися до несприятливих факторів навколишнього середовища, запобігти захворюванням та виявляти антиоксидантну активність.

Саме тому здорове харчування стало найважливішим глобальним трендом сучасного ринку продуктів харчування. Традиційна сировина для отримання харчових продуктів у харчовому та біологічному відношеннях недостатньо повноцінна, тому найбільш перспективним $\epsilon$ застосування цінних рослинних інгредієнтів. Окислювальне прогіркання - найбільш поширений вид псування жировмісних харчових продуктів, у результаті якого утворюються сполуки перекисного характеру, альдегіди, кетони, низькомолекулярні кислоти, оксикислоти та ін. У зв'язку з цим створення оздоровчих продуктів нового покоління з біологічно цінної сировини з антиоксидантними властивостями $€$ важливим товарознавчим науковим напрямом сьогодення.

Проблема пошуку та дослідження рослинних інгредієнтів 3 антиоксидантною дією залишається на сьогодні досить актуальною, проте не вирішеною. 3 метою отримання конкурентоспроможної харчової продукції сучасні тенденції орієнтують науковців на пошук ефективних природних джерел рослинних інгредієнтів, які виявляють комплексну позитивну дію на організм, зокрема антиоксидантну. Водночас необхідно намагатися застосовувати рослини з мінімальним ступенем технологічної обробки для збереження всього комплексу наявних біологічно активних речовин. Збагачення продукції рослинними антиоксидантами дозволить замінювати ними синтетичні. Потенційні можливості для використання альтернативних замінників синтетичних антиоксидантів достатньо великі, роботу в цьому напрямку проводять вчені світу. Для збагачення продукції антиоксидантами доцільно використовувати рослинні інгредієнти (Басов і Биков, 2013; Макарова та ін., 2013). Показано антиокислювальну дію порошку з плодів калини (Mazur, 2007). Встановлено, що етанольні екстракти стеблини рослини ентади (Dong et al., 2012), плоди пальми jussara (Da Silva et al., 2014), насіння кенафа (Mariod et al., 2014), екстракт рослини Sambucus nigra (Bratu et al., 2014) мають значну антиоксидантну активність і можуть розглядатися як джерело природних антиоксидантів. Активність антиоксидантів та інтенсивність окислювальних процесів у харчових продуктах залежить від жирнокислотного складу ліпідів, присутності різних інших інгібіторів або прооксидантів окислення, кількості і стану води у виробах, мікроструктури виробів, температури зберігання та інших факторів. Отже, саме тому виникає необхідність у проведенні експериментальних досліджень конкретних антиоксидантів по відношенню до різних видів жиру.

\section{Матеріали та методи}

Матеріалами експериментальних досліджень був жир кондитерський для вафельних і прохолоджувальних начинок серії «Віолія» ПАТ «Вінницький олійно-жировий комбінат» (ТУ У 15.4-00373758-007-2002; Висновок державної санітарно-епідеміологічної експертизи від 13.12.2011 р. за № 05.03.02-04/120053), що використовується як жирова основа борошняних кондитерських виробів, а також рослинні інгредієнти у вигляді порошків високої дисперсності (розмір частинок не більш як 100 мкм) квіток бузини чорної Sambucus nigra L. і квіток липи серцелистої Tilia cordata Mill. Порошки вносили в жир у концентрації 1 та 2 \% до маси жиру. Зразок жиру бездобавокслугував контролем. Експериментальнідослідженняздійснювали вмодельних умовах прискорено-кінетичним методом за температури $(90 \pm 2){ }^{\circ} \mathrm{C}$ з вільним доступом кисню повітря. Зміну якості жиру контролювали за органолептичними показниками та за вмістом продуктів окислення - первинних (пероксидне число, П.ч.), вторинних (бензидинове, Б.ч.) і продуктів гідролізу (кислотне число, К.ч.). Методи досліджень використовувались: фізикохімічні та аналітичні. 


\section{Результати та їх обговорення}

Відповідно до результатів досліджень, накопичення продуктів окислення в контрольному зразку жиру та зразках жиру з рослинними інгредієнтами виражалося, перш за все, в рості пероксидного числа. При цьому криві, що характеризують динаміку окислення жиру без добавок, мали більш високі темпи росту. Серед досліджених рослинних інгредієнтів порошок квіток бузини в концентрації 1,0% до маси жиру забезпечив зниження величини П.ч. в 1,3 - 1,55 рази (табл. 1).

Таблиця 1 Динаміка пероксидного числа кондитерського жиру з рослинними добавками (\%) в процесі зберігання в модельних умовах за температури $(90 \pm 2)^{\circ} \mathrm{C}$, ммоль $1 \frac{1}{2} \mathrm{O} / \mathrm{kr}$

Table 1 Dynamics of peroxide number of confectionery fat with plant additives (\%) during storage in the model conditions under the temperature $(90 \pm 2)^{\circ} \mathrm{C}, \mathrm{mmol} 1 / 2 \mathrm{O} / \mathrm{kg}$

\begin{tabular}{|l|c|c|c|c|c|}
\hline \multirow{2}{*}{$\begin{array}{l}\text { Добавки, } \\
\text { \%о маси жиру }\end{array}$} & \multicolumn{5}{|c|}{ Тривалість зберігання, діб } \\
\cline { 2 - 6 } & $\mathbf{2}$ & $\mathbf{4}$ & $\mathbf{6}$ & $\mathbf{8}$ & $\mathbf{1 0}$ \\
\hline Контроль & $5,992 \pm 0,299$ & $15,210 \pm 0,761$ & $28,115 \pm 1,405$ & $44,350 \pm 2,217$ & $58,760 \pm 2,938$ \\
\hline Квіти бузини, 1,0 & $4,609 \pm 0,234$ & $10,868 \pm 0,543$ & $18,869 \pm 0,943$ & $28,612 \pm 1,430$ & $37,909 \pm 1,899$ \\
\hline Квіти бузини, 2,0 & $4,438 \pm 0,222$ & $10,351 \pm 0,517$ & $18,619 \pm 0,930$ & $27,893 \pm 1,394$ & $36,725 \pm 1,836$ \\
\hline Квіти липи, 1,0 & $4,132 \pm 0,207$ & $9,392 \pm 0,469$ & $17,039 \pm 0,851$ & $25,635 \pm 1,281$ & $34,162 \pm 1,708$ \\
\hline Квіти липи, 2,0 & $3,994 \pm 0,199$ & $9,111 \pm 0,456$ & $16,251 \pm 0,812$ & $24,776 \pm 1,238$ & $32,109 \pm 1,605$ \\
\hline
\end{tabular}

$$
p \leq 0,05 ; n=3
$$

3більшення концентрації порошку до 2,0 \% обумовило створення ефекту антиокислення в 1,34 - 1,6 раза. За значенням П.ч. порошок квіток липи $(1,0 \%)$ перевищив ефективність квіток бузини (1,0 \%) в 1,1 рази. В зразку жиру з цією добавкою вміст пероксидів знижено в 1,36 - 1,72 рази за весь період зберігання. При близькій величині ступеня первинного окислення в зразку жиру з добавкою 2,0 \% порошку квіток липи все ж таки кількість пероксидів вдалося знизити в 1,39-1,83 рази в порівнянні з 1,0 \% цієї добавки.

Виявлено наявність антиоксидантних властивостей рослинних порошків також у серійних дослідах за показником Б.ч. (табл. 2).

Таблиця 2 Динаміка бензидинового числа кондитерського жиру з рослинними добавками в процесі зберігання в модельних умовах за температури $\left(90 \pm 2{ }^{\circ} \mathrm{C}\right), \mathrm{E}_{1 \mathrm{~cm}}^{1 \%}$

Table 2 Dynamics of benzidine number of confectionery fat with plant additives (\%) during storage in the model conditions under the temperature $\left(90 \pm 2{ }^{\circ} \mathrm{C}\right), \mathrm{E}_{1 \mathrm{~cm}}^{1 \%}$

\begin{tabular}{|l|c|c|c|c|c|}
\hline \multirow{2}{*}{$\begin{array}{l}\text { Добавки, } \\
\text { \% до маси жиру }\end{array}$} & \multicolumn{5}{|c|}{ Тривалість зберігання, діб } \\
\cline { 2 - 6 } & $\mathbf{2}$ & $\mathbf{4}$ & $\mathbf{6}$ & $\mathbf{8}$ & $\mathbf{1 0}$ \\
\hline Контроль & $0,158 \pm 0,008$ & $0,380 \pm 0,019$ & $0,510 \pm 0,026$ & $0,744 \pm 0,037$ & $0,942 \pm 0,048$ \\
\hline Квітки бузини, 1,0 & $0,131 \pm 0,007$ & $0,271 \pm 0,014$ & $0,346 \pm 0,018$ & $0,489 \pm 0,025$ & $0,611 \pm 0,031$ \\
\hline Квітки бузини, 2,0 & $0,127 \pm 0,007$ & $0,354 \pm 0,018$ & $0,340 \pm 0,018$ & $0,480 \pm 0,024$ & $0,603 \pm 0,030$ \\
\hline Квітки липи, 1,0 & $0,121 \pm 0,006$ & $0,253 \pm 0,013$ & $0,320 \pm 0,016$ & $0,453 \pm 0,023$ & $0,554 \pm 0,028$ \\
\hline Квітки липи, 2,0 & $0,117 \pm 0,006$ & $0,246 \pm 0,012$ & $0,312 \pm 0,016$ & $0,442 \pm 0,022$ & $0,547 \pm 0,027$ \\
\hline
\end{tabular}

$p \leq 0,05 ; n=3$ 
Встановлено достовірне зниження інтенсивності глибоких окислювальних перетворень у зразках кондитерського жиру з порошками квіток бузини у 1,20 - 1,54 рази та квіток липи 1,3-1,7 рази.

Спостерігались відмінності стабілізувальної дії добавок за результатами вивчення гідролітичних змін у жирі (табл. 3), які, очевидно, обумовлені особливостями складу різної рослинної сировини.

Таблиця 3 Динаміка кислотного числа кондитерського жиру з рослинними добавками в процесі зберігання в модельних умовах за температури $\left(90 \pm 2^{\circ} \mathrm{C}\right), \mathrm{Mr} \mathrm{KOH}$

Table 3 Dynamics of acid number of confectionery fat with plant additives (\%) during storage in the model conditions under the temperature $\left(90 \pm 2^{\circ} \mathrm{C}\right), \mathrm{mg} \mathrm{KOH}$

\begin{tabular}{|l|c|c|c|c|c|}
\hline \multirow{2}{*}{$\begin{array}{l}\text { Добавки, } \\
\text { \%о маси жиру }\end{array}$} & \multicolumn{5}{|c|}{ Тривалість зберігання, діб } \\
\cline { 2 - 6 } & $\mathbf{2}$ & $\mathbf{4}$ & $\mathbf{6}$ & $\mathbf{8}$ & $\mathbf{1 0}$ \\
\hline Контроль & $0,39 \pm 0,02$ & $0,52 \pm 0,03$ & $0,89 \pm 0,05$ & $1,18 \pm 0,06$ & $1,42 \pm 0,07$ \\
\hline Квіти бузини, 1,0 & $0,33 \pm 0,02$ & $0,40 \pm 0,02$ & $0,65 \pm 0,03$ & $0,83 \pm 0,04$ & $0,93 \pm 0,05$ \\
\hline Квіти бузини, 2,0 & $0,32 \pm 0,02$ & $0,39 \pm 0,02$ & $0,59 \pm 0,03$ & $0,78 \pm 0,04$ & $0,91 \pm 0,05$ \\
\hline Квіти липи, 1,0 & $0,32 \pm 0,02$ & $0,38 \pm 0,02$ & $0,57 \pm 0,03$ & $0,71 \pm 0,04$ & $0,83 \pm 0,04$ \\
\hline Квіти липи, 2,0 & $0,31 \pm 0,02$ & $0,36 \pm 0,02$ & $0,55 \pm 0,03$ & $0,69 \pm 0,04$ & $0,82 \pm 0,04$ \\
\hline
\end{tabular}

$$
p \leq 0,05 ; n=3
$$

Процес гідролізу менш інтенсивно відбувався в ліпідному комплексі з добавкою порошку квіток липи - в 1,2 - 1,71 рази, а порошку квіток бузини - в 1,15 - 1,52 рази. Збільшення концентрації добавок до 2,0 \% призвело до відповідного зростання інгібірувальної дії.

\section{Висновки}

На підставі проведених досліджень можна зробити висновок, що вивчені рослинні добавки у вигляді порошків квіток бузини чорної та липи серцелистої мають здатність уловлювати вільні радикали, запобігаючи окисленню ліпідів, виявляти відновлювальні властивості. Таким чином, антиокислювальні властивості добавок визначаються ступенем гальмування процесів окислення та гідролізу в 1,2 - 1,83 рази, що гіпотетично варто враховувати в подальших дослідженнях. Одержані результати обумовлюють можливість використання таких добавок як рослинних інгредієнтів у виробництві жировмісної борошняної кондитерської продукції підвищеної біологічної цінності для подовження термінів ії̈ зберігання.

\section{Література}

Bratu, M., Doroftei, E., Porta, S. 2014. Determination of antioxidant activity and toxicity of Sambucus nigra fruit extract using alternative methods. Food Technol. and Biotechnol, vol. 50, no 2, p. 177-182. DOI: 10.17113.

Da Silva, C., Kunradi, V., Copetti, C. 2014. Chemical characterization, bioactive compounds, and antioxidant capacity of jussara fruit from Atlantic Forest in southern Brazil. Food Res Int., vol. 44, no. 7, p. 2128-2133. DOI: 10.1111.

Dong, Y., Yang, H., Peng, Y., Wang, M. 2012. Antioxidant of phenolic compounds from the stems of Entada phaseoloides. Chem. and Biodivers, vol. 9, no 1, p. 68-79. ISBN 1612-1880.

Mariod, A., Ibrahim, R., Ismail, M., Ismail, N. 2014. Antioxidant activity of phenolic extracts from kenaf seedcake. Grasas y aceites, vol. 63, no. 2, p. 167-174. DOI: 10.3989 
Mazur, B., Borowska, E.J. Produkty z owoców zurawiny błtnej - zawartość zwiazków fenolowych i właściwości przeciwutleniajace. Bromatol. i chem. Toksykol, vol. 40, no 3, p. 239-243.

Басов, А.А., Быков, И.М. 2013. Сравнительная характеристика антиоксидантного потенциала и энергетической ценности некоторых пищевых продуктов. Bonросы питания, т. 82, № 3, c. 77-80. DOI: 10.21267.

Макарова, Н.В., Дмитриева, А.Н., Мусиффулина, Э.В. 2013. Ягоды - исходное сырьё с антиоксидантними свойствами. Пищевая промышленность, № 4, с. 25-27. DOI: 10.1016. 